\title{
PTERIDOSPERMOUS PLAN'TS FROM THE PENNSYLVANIAN OF ILLINOIS AND MISSOURI ${ }^{1}$
}

\section{Chester A. Arnold and Waldo E. Steidtmann}

IN THIs account a structurally preserved petiole and seed with features indicative of the Medulloseae are described as new, and some remarks are made concerning a specimen of Crossotheca sagittata (Lesquereux) Sellards, which supposedly represents the Lyginopterideae.

The Medulloseae are a group of pteridosperms having polystelic stems, large petioles with scattered bundles, and large seeds with a free integument and a double vascular system. There is considerable reason to believe that the well known Carboniferous leaf genera, Alethopteris and Neuropteris, represent medullosan foliage, and that the large campanulate spore-bearing organs of the Codonotheca and Whittleseya types are the microsporangiate structures. The structurally preserved petioles of the Medulloseae are known as Myeloxylon, and although the connection of these with stems of Medullosa has been demonstrated upon several occasions, the name is retained as a convenient designation for isolated specimens which cannot be assigned to the proper stem species. Myelopteris and Stenzelia are other names that have been used instead. Since the leaves of Medullosa were large, their supporting structures were strong, and petioles as much as $10 \mathrm{~cm}$. in diameter are known. It is generally assumed that Medullosa produced seeds, although the actual connection between a medullosan stem and seed has never been observed. On the other hand, the attachment of seeds to fronds of Alethopteris and Neuropteris has been demonstrated, and there is ample evidence, anatomical and otherwise, of a relation of these dominant foliage types to the medullosan complex.

The seed here deseribed as Rotodontiospermum illinoense is referred to the Medulloseae because of certain structural features which seem to ally it with Trigonocarpus, one species of which is supposed to be the seed of Medullosa anglica. Also, $R$. illinoense occurs in intimate association with medullosan foliage and stems.

Crossotheca is an epaulet-shaped organ which at different times has been interpreted both as the fertile pinnule of a Paleozoic fern and the microsporangiate structure of Lyginopteris. The former view was held before the pteridosperms were discovered. However, recent work has shown that the supposed connection of Crossotheca with Lyginopteris oldhamia can no longer be upheld, and as a consequence neither the microspore producing organs of $L$. oldhamia nor the affinity of Crossotheca are positively known. In this account Crossotheca is tentatively retained within the Pteridospermeae.

Myeloxylon missouriensis sp. nov.-Figures 6-10.

The specimen described here was collected by $\mathrm{Mr}$. J. B. Kleihege at Kansas City, Missouri, from the

${ }^{1}$ Received for publication August 2, 1937.
Chanute shale of the Kansas City group of the Missouri series. The Missouri series is essentially equivalent to the Monongahela of the Appalachian region and hence comparable to the upper part of the Westphalian of Europe. The specimen is therefore of approximately middle Pennsylvanian age.

The petiole (fig. 6) is well preserved and measures $16 \times 23 \mathrm{~mm}$. in diameter. In cross section it is incomplete, but judging from the preserved portion, the original area was probably twice as great. The petiole bases of Medullosa were flattened at the point of attachment to the stems, and the fact that the specimen under consideration is rounded in cross section indicates that it represents a portion some distance above the stem. The epidermis is not preserved, so the outermost tissue present is the layer of hypodermal sclerenchyma which is usually well developed in organs of this type. Internal to the sclerenchyma is the ground tissue containing numerous vascular bundles and gum canals.

A prominent feature in this specimen is what appears to be an abnormal thickening of the cell walls. This thickening extends throughout the entire extent of the ground tissue (fig. 8) and even into the phloem where thin walled tissue occurs normally. The structure is suggestive of a plant with an extraordinary development of sclerenchyma and which as a consequence was hard and woody. However, a careful examination of the cell walls shows that most of the thickening is probably due to the apposition of mineral matter. A layer of mineral matter may be seen covering the secondary walls of the tracheids, and in the phloem, where the structure is preserved, the cell cavities are nearly filled, giving the cells a peculiar sclerotic appearance. On the other hand, there is some reason to believe that the cells of the ground tissue were considerably thickened during life because no distinction can be made between wall and apposed mineral matter. The primary wall can be distinguished at some places as a thin dark line between the cells, but the thickened layer on the lumen side of the cell is of uniform structure. The thickness of these walls might have been increased by swelling during fossilization. However, one fact that leads to the betief that the ground tissue was originally rather firm is that no crushing of the specimen has taken place, as would be expected in material without special supporting mechanisms. Most of the cell cavities are empty except for the black gummy substance which fills many of them, especially in the vascular bundles.

Ground tissue (fig. 6). - In transverse section the cells of the ground tissue appear hexagonal. In size they range up to 220 micra in diameter, although the majority of them are smaller. Intercellular spaces may also be seen. In longitudinal section the cells appear short and square or broadly rectangular, with 
the transverse diameters slightly greater than the vertical.

As stated above, the thickening of the cell walls of the ground tissue is a striking feature which may be partly due to mineralization.

Peripheral sclerenchyma (fig. 6, 7).-This layer is about $1 \mathrm{~mm}$. thick, and consists of a zone of fibrous strands separated from one another by extensions of the ground tissue. These intervening layers of ground tissue are thin, seldom more than one or two cells thick. The strands may be slightly elongated radially, or they may be rounded, and one or two of them may constitute the extent of the layer. The sclerenchyma cells are small and thick walled. Occasional gum canals occur in the thin layers of ground tissue which intervene between the fibrous strands. The sclerenchyma zone is sharply delimited on the inside, there being no mingling of the fibrous strands with the bundles, as may be observed in some other species of Myeloxylon. No other true fibers are present in the petiole except for what appears to be a narrow zone of thick walled cells surrounding each vascular bundle.

Vascular bundles (fig. 10).- About sixty vascular bundles occur scattered throughout the preserved portion of the ground tissue, but more would be present in a complete specimen. At a slight distance inward from the inner margin of the sclerenchyma the bundles appear to be arranged in a rather definite ring, but otherwise no orderly arrangement can be noted.

The xylem consists of a mass of five or six, or sometimes more, spiral tracheids which fit compactly together without intervening parenchyma. Many of them are filled with black structureless material that obscures the details rather badly. When viewed in longitudinal section the tracheids show secondary thickenings of the closely wound spiral type (fig. 9). The intervening spaces are narrow, thus presenting an appearance which, it seems, is frequently interpreted as the scalariform condition. Many of the tracheids are quite large, some having a diameter of 200 micra. Since no end walls have been seen; it is unknown whether these conducting elements are true tracheids or vessels of the type sometimes occurring in ferns. Their size is suggestive of the latter. The smallest xylem cells are situated adjacent the phloem. The exact position of the protoxylem is obscured because of the accumulation of black material in the cells, but the exarch condition is probable, as in other species of the genus.

The phloem occupies a space about equal to or slightly larger than that of the xylem, but is separated from it by a narrow zone of cells. In most instances the phloem cells have entirely disappeared leaving only a mineral or debris filled cavity (fig. 10). In the few instances where the cells remain the structure of the tissue is obscured by the false thickening of the walls by mineral accretion. The occurrence of large gum-filled cavities adjacent to the xylem has previously been noted in Myeloxylon as it is mentioned by both Renault (1876) and Williamson (1876).
At first Williamson was unable to offer a satisfactory explanation for the existence of these cavities in connection with the vascular bundles, but later he concluded that they were the result of shrinkage. Renault appears to have reached the same conclusion. More recently, well preserved phloem cells have been observed, but it is a noteworthy fact that these cavities occur frequently in Myeloxylon.

The bundle is surrounded by a zone of thick walled supporting cells which is probably of the nature of a bundle sheath.

Gum canals (fig. 8).-These structures are circular in cross section, about 225 micra in diameter and fairly regular in size. Most of them are partially filled with black material similar to that seen in the tracheids and in some of the cells of the ground tissue. Surrounding the canal is a single layer of differentiated cells with short radial diameters which probably constituted the secretory tissue.

The gum canals are distributed throughout the ground tissue. They extend, as stated above, into the sclerenchymatous zone at the border, and somewhat exceed the bundles in number. Lining the canal is a layer of mineral matter which gives the canal the appearance of a large cell with a thick wall.

It is possible to compare Myeloxylon missouriensis with a few other medullosan petioles, but the variation in structure in different parts of the organ makes critical comparison uncertain. In the best known species of Medullosa, $M$. angelica, the amount of peripheral sclerenchyma becomes less in the upper portions, and it is on the basis of the amount and distribution of the sclerenchymatous bundles that most of the so-called species are differentiated. Structural changes at different levels similar to those of $M$. anglica are to be expected in other species.

So far only two structurally preserved medullosan petioles have been described from North America. The first was Myelopteris topekensis, of Penhallow (1897). Unfortunately little is known concerning the locality or geological horizon from which it came other than the mere statement that it was secured from the Upper Carboniferous at Topeka, Kansas. The assumption is, therefore, that it was derived from the Virgil series, which lies considerably above the Kansas City group. It is, for this reason, to be considered younger than our species.

$M$, topekensis is very poorly preserved. Only a few structural features are determinable and much of the general organization is obscure. If the badly crushed specimen accurately reveals the distribution of the sclerenchyma strands, it is apparent that the distribution varies from that in $M$. missouriensis. The strands in $M$. topelensis are separated from one another by broad zones of parenchyma, and the outermost vascular bundles appear to intermingle with the innermost sclerenchyma strands. Also, these latter strands seem to be tangentially elongated. The innermost sclerenchyma cells appear to be thinner walled than the outermost ones, which is an additional point of difference between this form and $M$. missouriensis, where the sclerenchyma is uniform throughout. The 

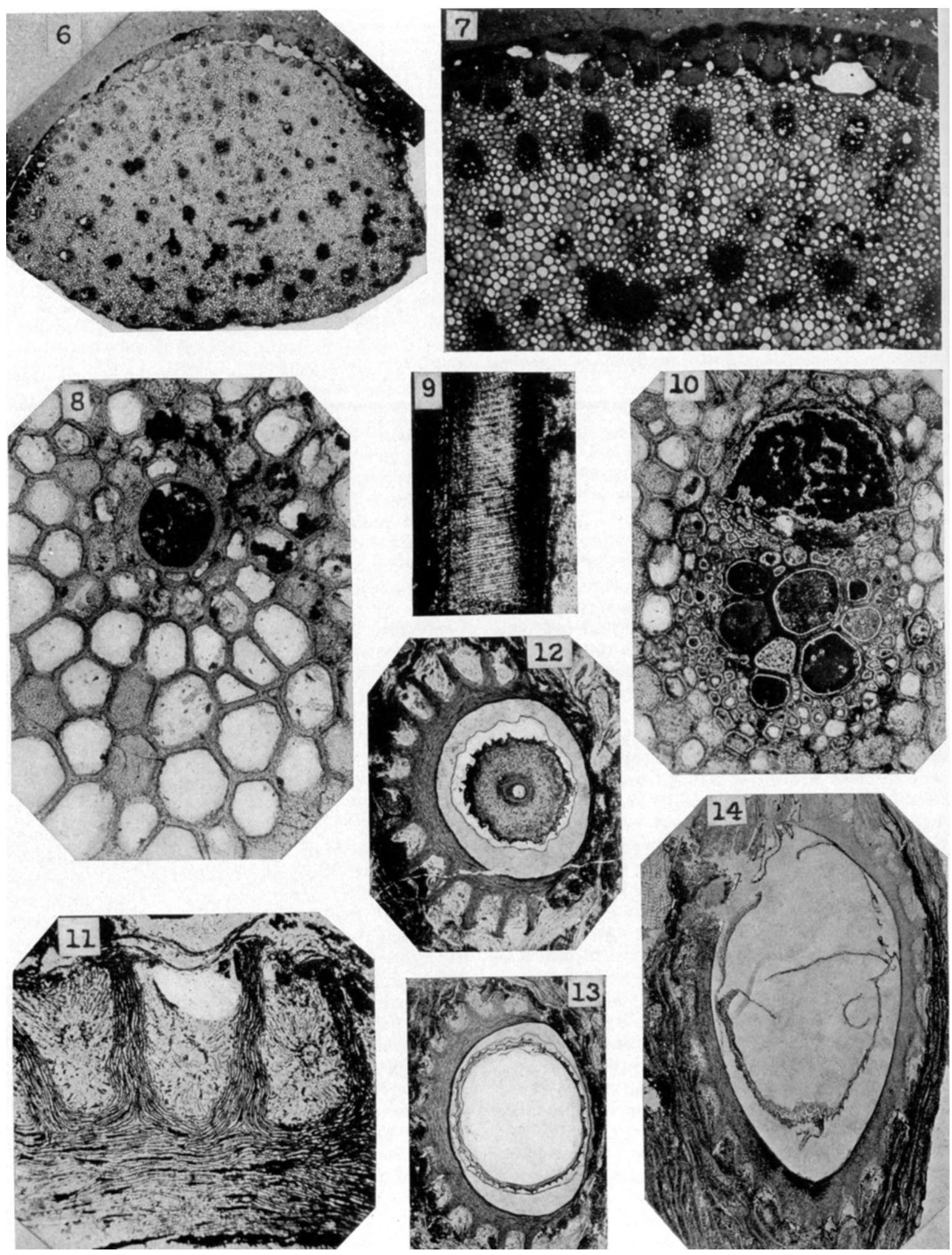

Fig. 6-14.-Fig. 6-10. Myeloxylon missouriensis.-Fig. 6. Cross section of petiole. $\times$ 3. - Fig. 7. Outer portion showing structure of the hypodermal sclerenchyma layer and distribution of the outermost bundles. $\times 9 .-$ Fig. 8 Detail of gum canal and ground tissue, showing the thickened walls of the latter. $\times 65 .-$ Fig. 9. Longitudinal 
bundles of the two forms are essentially alike, but the other differences just noted, along with probable differences in age, appear to justify the inclusion of the Kansas City specimen in a new species.

The only other structurally preserved medullosan petioles known from North America occur in the Illinois coal balls. The petiole of Medullosa Noci, from the McLeansboro formation, recently mentioned in a preliminary account by Steidtmann (1937), may be compared with Myeloxylon missouriensis in some detail. This petiole varies in known dimensions from a width of 10 or $12 \mathrm{~cm}$. where the leaf base departs from the stem to a diameter of $1 \mathrm{~cm}$. some distance away. Above, there is a reduction in the number of sclerenchyma strands, which become radially elongated in a manner somewhat resembling those figured for Myeloxylon radiatum, but remain in a single row. However, the strands of $M$. Noei seldom contain gum canals. The walls of the sclerenchymatous strands are rather thin and resemble collenchyma more than sclerenchyma. In the larger petioles the sclerenchyma zone consists of several rows of small, slender, radially elongated fiber strands, and inward from this there is a row of vascular bundles. Then, inside of this is a row of gum canals, each. partially surrounded by fibrous cells. The situation described above does not exist so markedly in Myeloxylon missouriensis.

The various forms of Myeloxylon described by European authors agree with $M$. missouriensis in their general structural plan, but differ in detail. Exact comparisons are, however, rather difficult to make. Considerable resemblance to $M$. radiatum may be noted.

The scattered arrangement of the bundles and the structure and distribution of the sclerenchyma strands have, in the past, provided a basis for comparison of Myeloxylon with living types such as the ferns and cycads, but since the attachment of Myeloxylon to Medullosa stems has been demonstrated several times within recent years, the question is largely solved as far as immediate affinities are concerned. The problem of Myeloxylon is simply that of the affinities of the Pteridospermeae as a plant group. The attachment of the petiole and stem was first established by Weber in 1880 . This, however, was before the discovery of the pteridosperms, and as a consequence the older literature is replete with discussions and arguments concerning the affinities of Myeloxylon. The scattered condition of the vascular bundles first led to the supposition that it was a monocotyledon of the palm or Dracaena type. As subsequent investigations led to a better understanding of its anatomy, and as living plants also became better known, it was compared in detail with certain ferns, especially Angiopteris. The contention that Myelopteris was a fern was stoutly maintained by many. Other investigators compared it with the petioles of certain cycads, the contention being that the position of the protoxylem was incompatible with the ferns.

Attempts have again been made within recent years to interpret Myeloxylon as an angiosperm, but. without general acceptance. The exarch position of the protoxylem observed in several species, including $M$. Noei, is decidedly against the possibility that certain of the unattached specimens may actually represent monocotyledonous stems.

The following diagnosis of Myeloxylon missouriensis sp. nov., may be given: Petiole of medium size, measuring $16 \times 23 \mathrm{~mm}$., but incomplete; cells of ground tissue large, 5- or 6-sided in cross section with transverse walls horizontally placed, generally slightly wider than high, walls considerably thickened; peripheral sclerenchyma zone about $1 \mathrm{~mm}$. thick, consisting of one or two layers of round or radially elongated strands separated by thin zones of ground tissue; strands consisting of small, thick walled fibers; vascular bundles scattered, surrounded by bundle sheath of small cells; tracheids large, secondary thickenings a close spiral; gum canals scattered, extending into peripheral sclerenchyma zone, ducts about 225 micra in diameter and surrounded by a single layer of radially shortened secreting cells; phloem areas, tracheids, and gum canals frequently filled with black structureless material.

The type is No. 18045 of the University of Michigan Collection.

\section{Rotodontiospermum illinoense gen. et sp. nov.-} Figures 1, 11-14.

While studying the medullosan remains in coal balls from the McLeansboro formation of the Calhoun Mine in Richland County, Illinois, four partially preserved pteridospermous seeds were found. These seeds were found in intimate association with the petioles, stems, roots, and leaves of $M . N o e i$, all of which, except the leaves, were connected.

As for the possibility that these seeds also belong to $M$. Noei, there exists no direct evidence, since they were not attached to any other parts, but the close association renders the likelihood strong. It is entirely conceivable that future investigations of these coal balls will reveal actual attachment.

The seeds are all similar in size and appearance. Three are well preserved in part, but the fourth was badly crushed. All are rather large, 3 to $3.5 \mathrm{~cm}$. long and slightly more than $2 \mathrm{~cm}$. in diameter. They are

section of portion of tracheid, showing the closely wound spiral thickening. $\times 110 .-$ Fig. 10. Vascular bundle showing tracheids and debris filled phloem cavity. $\times 65$.

Fig. 11-14. Rotodontiospermum illinoense.-Fig. 11. Detail of testa, showing endotestal furrows containing vascular bundles, the endotestal projections, and the fibrous structure of the latter. $\times 12 .-$ Fig. 12 . Cross section through the lower portion of the seed showing the endotestal furrows, the cavity left by the shrinkage of the nucellus, the nucellus, and the vascular "cup" surrounding the central cavity. $\times 3$.-Fig. 13. Cross section similar to that shown in fig. 12 , but at a higher level. $\times 2$.-Fig. 14. Longitudinal-oblique section showing the thiekened nucellus in the basal portion, and the large endosperm cavity. $\times 2$. 

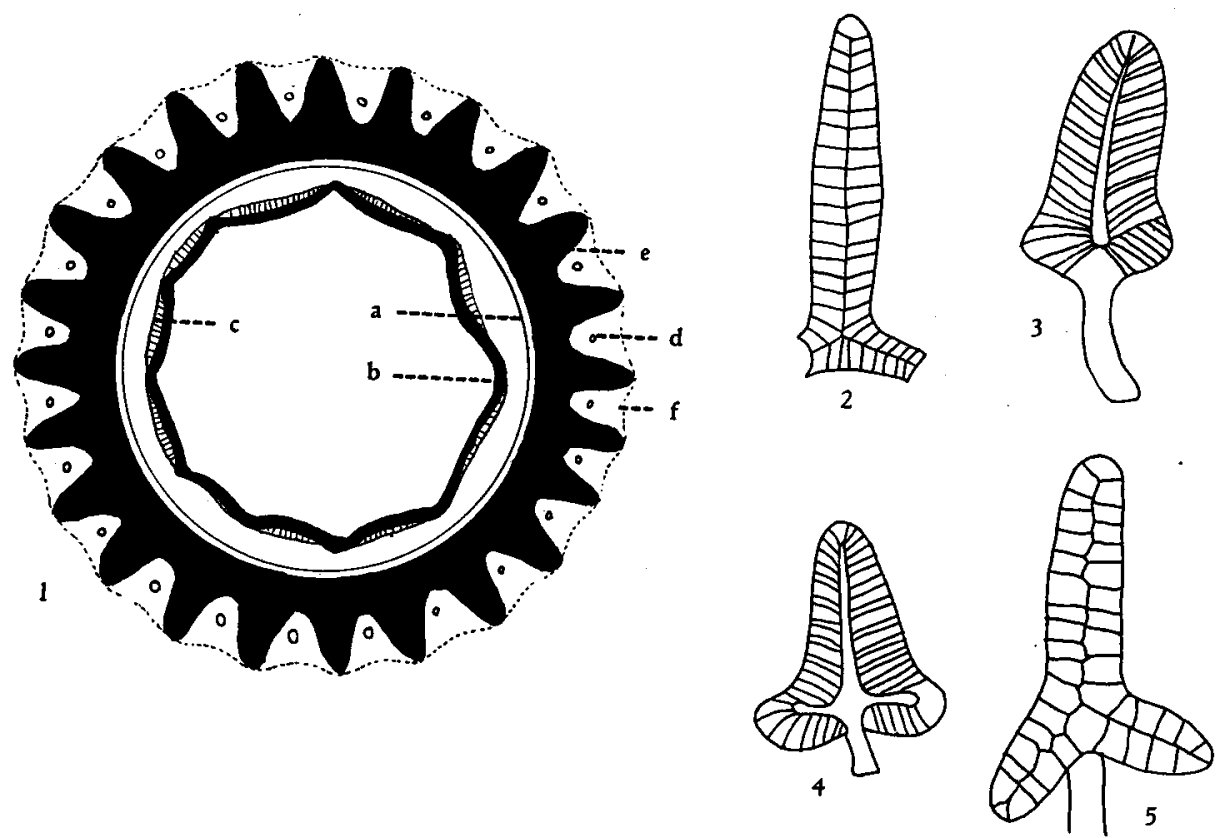

Fig. 1-5.-Fig. 1. Rotodontiospermum illinoense. Reconstruction of cross section. $a$, "inner flesh"; $b$, nucellus; $c$, position of vascular strand; $d$, vascular strand of testa; $e$, endotestal ridge; $f$, endotestal furrow. Diagrammatic. $\times$ about 21/2.-Fig. 2. Crossotheca Boulayi (after Kidston, 1923, p. 354, fig. 29A). Inserted for comparison with $C$. sagittata. $\times 3$.-Fig. 3, 4. C. sagittata (after Lesquereux, Coal Flora, Pl. XLVIII, fig. 10a, 10b). The figures show the sporangia around the margin of the lower surface of the limb, but they do not cover the entire lower surface.Fig. 5. C. sagiltata. Outline sketch showing the arrangement of the sporangia in the lower surface of the limb (Specimen no. 17838, Univ. Mich. Coll.). The outer margin of the limb is not shown. $X$ about $31 / 2$.

oval in shape, bulging slightly along the sides but somewhat flattened at the ends. The form is somewhat suggestive of Lagenostoma Lomaxi, although differing from that seed in other respects. The seed appears round in cross section (fig. 1, 12,13) although the presence of deep furrows in the endotesta indicates that corresponding shallower furrows might have existed on the outer surface. This, however, is only conjectural since the outermost tissues are not preserved. The ovate outline of the seed shown in figure 14 is due to the specimen having been cut on a slant.

While the size and shape of the seeds are well shown by the specimens at hand, the micropylar portion in all of them is crushed so that details of the apex and the pollen chamber are unfortunately undeterminable.

The feature shown by Rotodontiospermum which appears to distinguish it is the structure of the testa. The testa consists of an outer fleshy layer, the exotesta, of unknown thickness, and an inner tough or fibrous layer, or endotesta, 3 or $4 \mathrm{~mm}$. thick, which is deeply and evenly furrowed lengthwise of the seed (fig. 12, 13). Each furrow is filled with parenchymatous material containing a vascular strand. Separating the furrows are thin, outwardly radiating projections of fibrous material having a length greater than the thickness of the solid portion beneath (fig. 11). In a cross section of the seed, therefore, the endotesta resembles the rim of a $\operatorname{cog}$-wheel (fig. 1, 12). These endotestal extensions, or ribs, separating the furrows apparently divide as they extend from the base of the seed toward the apex. Sections through the base show about ten of these structures, while at higher levels twenty or more may be counted. The exact number is difficult to determine because of partial obliteration. These ribs are spaced from 1.5 to 2 millimeters apart. The tissue of the endotesta is fibrous and consists of long, intertwined, thread-like cells with rather thin walls of a brownish color. The structure of the endotesta is suggestive of a compact and leathery rather than a sclerotic layer. An obvious feature is that these intertwined cells are elongated in the direction of the circumference of the seed rather than lengthwise to it (fig. 11). The toughness of this layer probably served to give the seed coat considerable strength against internal stress and constituted an effective barrier against excessive water loss or fungous attacks. Within the radiating "teeth" the threads are directed outwardly. At their tips and along their sides the attachment of the adjacent parenchyma is evident.

Along the inner surface of the endotesta, and apparently belonging to it, is a thin layer which, to the unaided eye, appears as a lark line. This layer is about five cells thick and consists of cells vertically elongated and consequently placed approximately at right angles to the fibrous threads of the endotesta. These cells, with the exception of those of the innermost layer, have dark contents. In position this zone 
corresponds to a similar tissue in Trigonocarpus and certain other forms and which has been designated as the "inner flesh" (1923). It may be compared to the aleurone layer in some of the familiar monocotyledonous grains.

The internal structures of the seed are poorly preserved. The central portion formerly occupied by the female gametophyte is mostly filled with mineral matter. In common with other known Paleozoic seeds, no embryo can be seen. A thin nucellar layer, usually in a somewhat collapsed condition and separated from the endotesta by a mineral filled space, surrounds the central cavity (fig. 12, 13, 14). In the outer part of the nucellus a ring of vascular strands is visible.

The vascular system of the seed is double, one set of strands occupying the parenchyma filled furrows in the endotesta and the other occupying the nucellus. The origin of the vascular supply of the testa is not shown, as the strands leave the axis at a point below the preserved portion. The vascular system of the nucellus enters the chalazal region as a cup-like sheath at a place where the nucellus is thick (fig. 12, 14). This sheath separates into strands which ascend the nucellus, and near the equatorial region of the seed as many as ten or fifteen may be counted. Evidently these strands become smaller as the micropylar region is approached.

Rotodontiospermum illinoense resembles Trigonocarpus in having the double vascular system and a nucellus apparently free from the integument. It may therefore be referred to the Trigonocarpales. It differs from Trigonocarpus, however, in that the vascular strands in the testa follow the furrows of the endotesta instead of being opposite the ribs. Furthermore, Trigonocarpus has six endotestal bundles, whereas Rotodontiospermum has twenty or more. Another difference is that the inner testa in Trigonocarpus is always referred to as a sclerotesta, implying that it is a stony layer such as occurs in the seeds of cycads, instead of being leathery, and it is ornamented with three prominent ridges with smaller ones between. In Rotodontiospermum the ribs are of equal size (fig. 1). Trigonocarpus, however, appears to be one of the very few known structurally preserved Paleozoic seeds with which Rotodontiospermum may be compared.

Other structurally preserved seeds of similar age have been described by Krick (1932) from the coal balls at Harrisburg, Illinois, but only a specimen assigned to Trigonocarpus Parkinsoni is remotely suggestive of our material. However, it shows the distinct three-angled feature which definitely sets it off from Rotodontiospermum. The seeds described by Krick are said to be surrounded by the pinnae and petioles of Medullosa. Trigonocarpus is known in some instances at least to have been borne on Alethopteris fronds, and the latter are supposed to represent the foliage of some forms of the Medullosae. The double vascular system of Rotodontiospermum positively identifies it as a member of the Trigonocarpales, and its intimate association with Alethopteris and the stems and petioles of Medullosa constitutes circumstantial evidence of generic identity.

The following diagnosis may be proposed for the newly instituted genus Rotodontrospermum: Paleozoic seeds of the Trigonocarpales type; of large size, oval or slightly truncated in longitudinal section, circular in cross section; seed coat differentiated into distinct exotestal and endotestal layers, the endotesta of leathery and fibrous consistency, deeply furrowed longitudinally; furrows of equal depth and separated by narrow extensions of the endotesta; "inner flesh" thin, cells vertically elongated, with dark contents; vascular system double, supplying nucellus and exotesta, with a single strand traversing each endotestal furrow; endosperm large and filling the central cavity.

Rotodontiospermum ILLINOENSE sp. nov. Seed 3 to $3.5 \mathrm{~cm}$. in length and slightly more than $2 \mathrm{~cm}$. in diameter; endotesta composed of thread-like fibers elongated in the direction of the circumference of the seed; about 10 endotestal furrows at the base but 20 or more at higher levels; furrows 2 to $2.5 \mathrm{~mm}$. deep "inner flesh" about 5 cells in thickness, cells (with the exception of the innermost layer) with dark contents; nucellus thin; vascular strands of nucellus arising from a cup of vascular tissue situated in the chalazal portion of the seed.

The type is No. 18042 of the University of Michigan Collection.

\section{Crossotheca sagitta (Lesq.) Sellards.-Figure 5.}

Among the collection of plant fossils from Mazon Creek in the Museum of Paleontology of the University of Michigan are the two halves of a split nodule containing a specimen labeled Staphylopteris sagittatus, a species originally described by Lesquereux (1870), but later transferred to the new genus Sorocladus (1880). S. sagittatus was later shown by Sellards to belong to Crossotheca (1902).

Crossotheca sagittata has been recently refigured and partially described by Darrah (1937). Our specimen agrees in essential respects with the material figured by Darrah, but it shows some important differences from the species as originally figured by Lesquereux (1870) and later by Sellards (1902). In our specimen the pendulous sporangia are arranged in two parallel rows on the lower surface of a hastate limb (fig. 5). The sporangia of the adjacent rows touch at their bases, thus completely covering the lower surface. Two rows also extend along each basal cusp. The figures by Lesquereux show the sporangia arranged as a fringe around the lower margin of a sagittate limb with the surface of the inner part of the limb exposed (fig. 3,4 ). Lesquereux apparently considered the fertile pinnules a capsule which opened at maturity. He might have observed the parallel arrangement of sporangia in what he considered to be immature specimens, because he says: "The double celled sporanges are linear, attached by their backs, and pressed against each other in horizontal rows" (1870, p. 407). Whether or not he was referring to the arrangement mentioned here is uncertain. However, his figures do not show it. 
The arrangement of the sporangia in our specimen is strikingly like material shown by Kidston (1923) and referred to Crossotheca Boulayi (fig. 2). Indeed the resemblance is so close, not only with respect to the arrangement of the sporangia but to the general shape of the pinnule as well, that one is inclined to suspect a close relationship if not specific identity between the two. Between C. Boulayi as figured by Kidston and $C$. sagittata as figured by Lesquereux and Sellards, our specimen along with those figured by Darrah shows a closer resemblance to the former. Kidston, when describing C. Boulayi, had material supposed to represent $C$. sagittata from Mazon Creek at hand for comparison, but he concluded that the two species are distinct. However, his account of the differences between the fertile pinnules of the two is confusing. He makes no reference to any similarity in the arrangement of the sporangia. The single specimen from Great Britain which he refers to $C$. sagittata is in all probability some other species.

Either the earlier figures of $C$. sagittata are in error or more than one species has been included under it. Both situations might well exist, but the final decision must rest upon the examination of a greater quantity of material than is available at present.

The specimen under consideration here is slightly smaller than C. Boulayi (of Kidston) or the specimens of $C$. sagittata figured by Darrah. For example, the sporangia in our specimen are but $2.5 \mathrm{~mm}$. long, whereas Darrah states that the length is $5 \mathrm{~mm}$. Darrah also says that "the small sagittate sporophylls bear 12 free, pendulous sporangia." In our specimen, however, forty-two sporangia may be counted on a single complete sporophyll (fig. 5).

Our specimen of C. sagittata may be briefly diagnosed as follows: Total length $4 \mathrm{~cm}$., width $3.5 \mathrm{~cm}$.; bipinnate pinnae alternately arranged; primary rachis $2 \mathrm{~mm}$. wide; total length of pinnae about $17 \mathrm{~mm}$.; fertile pinnules hastate, $9-10 \mathrm{~mm}$. long; basal cusps about $3 \mathrm{~mm}$. long and diverge at an angle of about 110 degrees; width between tips of cusps about 4 $\mathrm{mm}$.; limb fleshy and rounded on upper surface, about $3 \mathrm{~mm}$. broad, edges rolled downward and extending laterally slightly beyond the sporangia; sporangia pendulous and in two parallel contiguous rows on lower surface of limb, 30 or more per pinnule, length about $2.5 \mathrm{~mm}$., width about $.5 \times .75 \mathrm{~mm}$., with greatest diameter crosswise to length of limb; spores smooth, 43 to 58 micra in diameter; no sterile foliage present.

The exact dimensions of the limb are difficult to determine since most of the tissue has disappeared leaving only concavities in the rock. By pressing plasticine into these the original surface configuration is partially brought out. However, the pinnule is clearly a hastate structure, and not sagittate as the species was originally figured.

The specimen is No. 17838 of the University of Michigan Collection.

\section{SUMMARY}

Myeloxylon missouriensis, a structurally preserved petiole of the Medullosae, is distinct from the two previously described medullosan petioles from America. The peripheral sclerenchyma zone is narrow, and the strands are separated by intrusions of ground tissue. Scattered throughout the ground tissue are gum canals and collateral vascular bundles, the latter possessing tracheids of the closely wound spiral type. The phloem, in most instances, has disappeared, and the remaining cavities are filled with black structureless material. The walls of the cells throughout the petiole appear abnormally thickened by mineral accretion.

Rotodontiospermum illinoense is a structurally preserved seed intimately associated with medullosan remains. It is characterized by the presence of a fibrous, deeply furrowed endotesta. The double vascular system and the free nucellus indicate affinity with the Trigonocarpales.

A specimen of Crossotheca sagittata, from Mazon Creek, Illinois, shows sporangia arranged in a similar manner to those of $C$. Boulayi, and hence different from the arrangement as originally figured.

All the material described is of middle Pennsylvanian age.
University of Michigan, Ann Arbor, Michigan
Bowling Green State Untversity, Bowling Green, Ohio

\section{LITERATURE CITED}

Darrat, W. C. 1937. Codonotheca and Crossotheca: polleniferous structures of pteridosperms. Bot. Mus. Leaflet, Harvard Univ. 4: 153-172.

Kroston, R. 1923. Fossil plants from the Carboniferous rocks of Great Britain. Mem. Geol. Surv. Great Britain, Paleont. 2: 275-376.

Krick, H. V. 1932. Structure of seedlike fructifications found in coal balls from Harrisburg, 1llinois. Bot. Gaz. 93: 151-172.

LesquereuX, L. 1870. Descriptions of fossil plants. Geol. and Palaeont., 4: 377--508. Geol. Surv. Illinois.

- 1880. Description of the coal flora of the Carboniferous formation in Pennsylvania and throughout the United States. 2nd Geol. Surv. Pennsylvania, Rept. Progress P. Harrisburg.

Penhallow, D. P. 1897. Myelopteris topekensis, n. sp., a new Carboniferous plant. Bot. Gaz. 23: 15-30.
Renauri, B. 1876. Recherches sur les végétaux silicifiés d'Autun. Mem. pres. Div. Sav. à L'Acad. des Sci. 22.

Scort, D. H. 1923. Studies in fossil botany. Pt. 2.3 ed. London.

SEt.tards, E. H. 1902. On the fertile fronds of Crossotheca and Myriotheca, and on the spores of other Carboniferous ferns, from Mazon Creek, Illinois. Amer. Jour. Sci. 164: 195-202.

Steintmans, W. E. 1937. A preliminary report on the anatomy and affinities of Medullosa Noei sp. nov., from the Pennsylvanian of Illinois. Amer. Jour. Bot. 24: 124-125.

Williamson, W. C. 1876. On the organization of fossil plants from the Coal Measures. Pt. VII. Myelopteris, Psaronius, and Kaloxylon. Phil. Trans. Roy. Soc. London B 166: 1-25. 